\title{
Badania trwałości noży styczno-obrotowych wykonanych z różnych materiałów
}

\begin{abstract}
$W$ artykule zamieszczono informacje dotyczace noży styczno-obrotowych, które obecnie sa najpowszechniej stosowanymi narzędziami urabiajacymi. Opisano ich zastosowanie, budowę, sposoby zwiększania ich trwatości oraz problemy występujące podczas ich eksploatacji. Główna częścia artykułu sa wyniki badań trwałości noży styczno-obrotowych wykonanych $z$ różnych materiatów bądź napawanych lub obrobionych $w$ sposób zwiększający ich trwałość. Do badań wybrano noże wzorcowe, handlowe oraz noże prototypowe. Przedstawiono również specjalne nowoczesne stanowisko laboratoryjne do badania procesu urabiania przez frezowanie lub wiercenie obrotowe pojedynczymi narzędziami skrawającymi lub organami, należace do Katedry Maszyn Górniczych, Przeróbczych i Transportowych AGH w Krakowie, na którym przedmiotowe badania zostały wykonywane.
\end{abstract}

Słowa kluczowe: mechaniczne urabianie skat, noże styczno-obrotowe, trwałość, zużycie, stanowisko laboratoryjne

\section{WPROWADZENIE}

Drążenie wyrobisk chodnikowych i eksploatacja wyrobisk ścianowych odbywa się najczęściej za pomocą urabiania mechanicznego, które polega na bezpośrednim oddziaływaniu narzędziem lub zespołem narzędzi skrawających na caliznę skalną. Najbardziej powszechne jest urabianie skał przez frezowanie kombajnami oraz struganie strugami przy użyciu narzędzi skrawających (noże kombajnowe, strugowe) [1-3].

Obecnie zarówno w kombajnach chodnikowych, ścianowych, a nawet szybowych, najczęściej stosowane są noże styczno-obrotowe. Dzięki większej trwałości noże te prawie całkowicie wyparły starsze rozwiązania, czyli noże styczne płaskie oraz promieniowe. Ma to szczególne znaczenie dla zmniejszenia czasu wymaganego na ich wymianę oraz zużycie uchwytów i organów [3-5].

Noże styczno-obrotowe stosowane w organach kombajnów ścianowych (rys. 1a) charakteryzują się znaczną długością korpusu $\left(L_{n} \geq 80 \mathrm{~mm}\right)$ i smukłością. Ostrza tych noży zbrojone są węglikami o kącie zbieżności stożka $2 \beta_{u} \geq 93^{\circ}$. Również część chwytowa wprowadzana $\mathrm{w}$ uchwyt nożowy jest dłuższa i może być stopniowana. Nóż przed wypadnięciem z uchwytu zabezpieczany jest różnego typu zawleczkami, pierścieniami lub tulejkami. Noże kombajnów chodnikowych (rys. 1b) mocowane są w uchwytach przyspawanych do głowicy urabiającej zabudowanej na ramieniu maszyny. Są one w przeciwieństwie do noży kombajnów ścianowych krótsze i mniej smukłe, a węgliki stosowane na ostrza tych noży mają większe kąty zbieżności stożka [4-7].

Proces frezowania nożami styczno-obrotowymi wymaga od narzędzia takiego kształtu i wymiarów, aby jego ostrze zagłębiające się podczas pracy w caliznę na głębokość $g_{s}$ uzyskiwało właściwe ruchowe kąty skrawania. Szczególnie należy zwrócić uwagę na to, aby ostrze noża w procesie skrawania miało zawsze dodatni ruchowy kąt przyłożenia $\alpha_{r}[1,8]$.

Nóż zamocowany w uchwycie jest częścią organu (rys. 2), dlatego ruchowe kąty skrawania $\alpha_{r}$ i $\gamma_{r}$ zależą 
a)

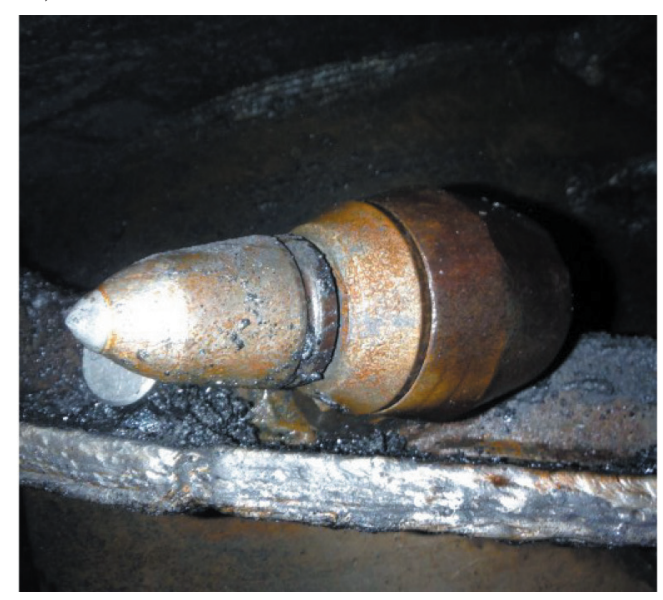

b)

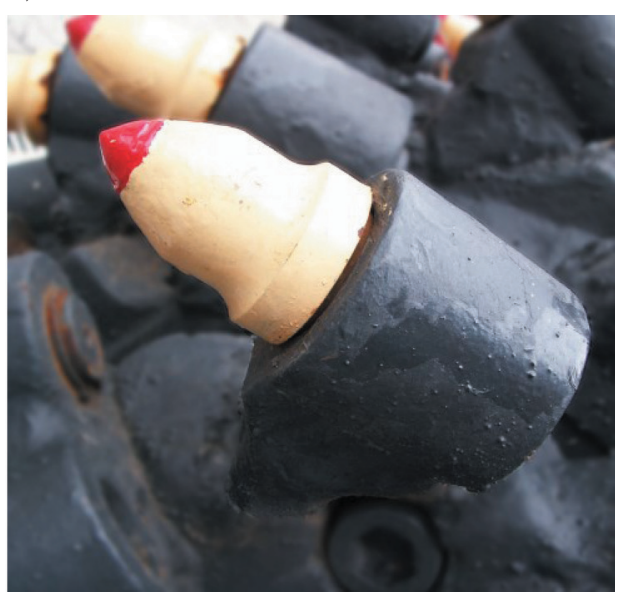

Rys. 1. Nóż styczno-obrotowy zamocowany na organie: a) kombajnu ścianowego; b) kombajnu chodnikowego

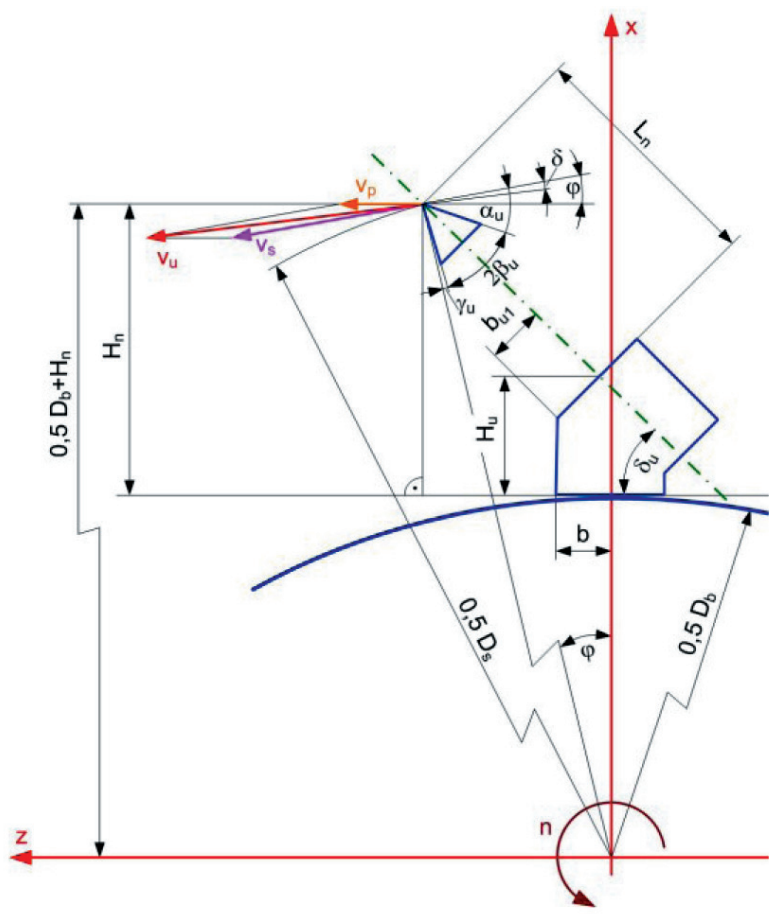

Rys. 2. Parametry ustawienia uchwytu i noża styczno-obrotowego na organie [6]

nie tylko od parametrów konstrukcyjnych noża, ale również uchwytu i organu, jak też od prędkości skrawania $v_{s}$ i posuwu $v_{p}$. Wynika stąd, że dla organu o średnicy $D_{s}$, prędkości skrawania $v_{s}$ i posuwu $v_{p}$, wysokości uchwytu $H_{u}$ i kącie $\delta_{u}$, należy dobrać nóż styczno-obrotowy o wymaganej długości $L_{n}$ i kącie ostrza $2 \beta_{u}$. Wtedy pozostałe parametry konstrukcyjne noża muszą mieć takie wartości, aby zapewnić najkorzystniejsze warunki urabiania [8-10]. Stąd też bardzo ważne jest zapewnienie takich parametrów konstrukcyjnych i kinematycznych noża, by uzyskać jak najmniejsze opory urabiania i jak najwyższą jego trwałość $[1,4,10]$.
Narzędzie skrawające podczas eksploatacji jest elementem będącym bezpośrednio w kontakcie $\mathrm{z}$ urabianą calizną. W wyniku procesu urabiania w strefie styku narzędzia ze skrawanym materiałem dochodzi do jego zużycia. Powoduje to zmiany zarówno kształtu geometrycznego noża, jak i ubytek jego masy. Szczególnie zmiana kształtu i ubytek masy części roboczej skutkuje wypadnięciem węglika, a tym samym utratą zdolności skrawających. Innym zagadnieniem jest uszkodzenie mechaniczne noża wynikające $\mathrm{z}$ niewłaściwej eksploatacji lub jego wykonania $[3,4,10]$.

O prawidłowej pracy noży decyduje nie tylko odpowiedni dobór parametrów konstrukcyjnych i kinematycznych noży, ale również technologia ich wykonania i rodzaj zastosowanych materiałów. Dlatego w celu zwiększenia trwałości noży obrotowych prowadzi się szereg badań nad opracowaniem nowych materiałów zarówno na ostrza, jak i korpusy tych narzędzi.

Ostrza aktualnie najczęściej wykonuje się z węglików spiekanych na osnowie kobaltu. Jednakże stosuje się również inne materiały na ostrze, np. cermetale, spieki ceramiczne czy diament polikrystaliczny [5, 7]. Cermetal (nazwa powstała z połączenia słów ceramika i metal) jest węglikiem spiekanym z twardymi cząstkami opartymi na tytanie. Początkowo cermetale były kompozytami TiC oraz niklu. Nowoczesne cermetale nie zawierają niklu i posiadają zaprojektowaną strukturę cząsteczek rdzenia $\mathrm{z}$ węglika tytanu Ti $(\mathrm{C}, \mathrm{N})$, drugiej twardej fazy z $(\mathrm{Ti}, \mathrm{Nb}, \mathrm{W})(\mathrm{C}, \mathrm{N})$ oraz bogatego w wolfram spoiwa kobaltowego. W grupie spieków ceramicznych możemy wyróżnić ceramikę tlenkową zawierającą głównie tlenek glinu 
$\left(\mathrm{Al}_{2} \mathrm{O}_{3}\right)$ oraz spieki ceramiczne azotkowe, zawierające głównie azotek krzemu $\left(\mathrm{Si}_{3} \mathrm{~N}_{4}\right)$. Natomiast diament polikrystaliczny (PCD) jest kompozytem cząsteczek diamentu zapieczonych razem $\mathrm{z}$ metalicznym spoiwem. Diament jest najtwardszym i najbardziej odpornym na ścieranie materiałem. Jako narzędzie skrawające charakteryzuje się wysoką odpornością na zużycie, ale niską stabilnością chemiczną w wysokich temperaturach i łatwo rozpuszcza się w żelazie $[5,7,11]$.

Uzyskuje się wtedy nóż, którego ostrze wykazuje dużą trwałość, jeżeli równolegle część robocza noża zabezpiecza węglik przed wypadnięciem. Stąd stosuje się wiele metod ograniczających szybkość zużycia się korpusu noża, a tym samym i wykruszanie węglików [3, 9].

$\mathrm{Na}$ korpusy noży styczno-obrotowych stosuje się stale o dużej udarności, wytrzymałości i odporności na ścieranie, które dodatkowo mogą być poddane procesowi nawęglania i obrabiane cieplnie [7, 12]. W celu ograniczenia zużycia wykonuje się również zabezpieczenie zewnętrznej powierzchni stożkowej noża warstwą odporną na ścieranie, wykonywaną metodą napawania (rys. 3b, c). Innym sposobem jest wykonanie na części atakującej korpusu noża dodatkowego pierścienia z węglika spiekanego (rys. 3a) $[5,10]$. Sposoby te zwiększają trwałość noży, lecz wymagane jest jej potwierdzenie na podstawie badań eksploatacyjnych lub laboratoryjnych.

Pomiar szybkości zużycia noży styczno-obrotowych ma na celu określenie ich trwałości. Pomiaru trzeba dokonywać zawsze w tych samych warunkach, tak by wyniki były wiarygodne, powtarzalne i probabilistyczne. Pozwoli to ocenić trwałość noża, ale również porównać $\mathrm{w}$ tym aspekcie różne noże. W warunkach przemysłowych trwałość noży skrawających określa się zazwyczaj jako stosunek liczby noży wymienionych do objętości urobionego minerału. Najczęściej jest to liczba noży zużytych na pozyskanie $1000 \mathrm{Mg}$ lub $1000 \mathrm{~m}^{3}$ urobku. Natomiast w warunkach laboratoryjnych szybkość zużycia noża czy noży (trwałość) najefektywniej można wyznaczyć poprzez ubytek masy w stosunku do urobionej przez nóż czy noże objętości próbki skalnej [8-10].

W niniejszym artykule przedstawiono wyniki badań, których celem był wcześniej wspomniany pomiar szybkości zużycia noży styczno-obrotowych, wykonanych z różnych materiałów. Porównano noże wzorcowe, handlowe oraz prototypowe. Badania przeprowadzono na specjalnym nowoczesnym stanowisku laboratoryjnym do badania procesu urabiania poprzez frezowanie lub wiercenie obrotowe pojedynczymi narzędziami skrawającymi lub organami, należącym do Katedry Maszyn Górniczych, Przeróbczych i Transportowych AGH Kraków.

\section{PRZEDMIOT BADAŃ}

Badaniami objęto osiem typów noży styczno-obrotowych wykonanych z różnych materiałów bądź napawanych lub obrobionych w sposób zwiększający ich trwałość. Wszystkie noże, oprócz wzorcowych, były nożami prototypowymi (rys. 4), o części roboczej długości $90 \mathrm{~mm}$ i kącie ostrza $2 \beta_{u}=90^{\circ}$. Siedem typów zbrojonych było węglikami spiekanymi, natomiast jeden typ wkładką ceramiczną. Do badań przeznaczono następujące noże:

- noże wzorcowe, handlowe $\mathrm{z}$ węglikiem $\phi 22$ 4 sztuki - oznaczone jako „handlowy 22”,

- noże wzorcowe, handlowe $\mathrm{z}$ węglikiem $\phi 25$ 4 sztuki - oznaczone jako „handlowy 25” (rys. 4c), a)

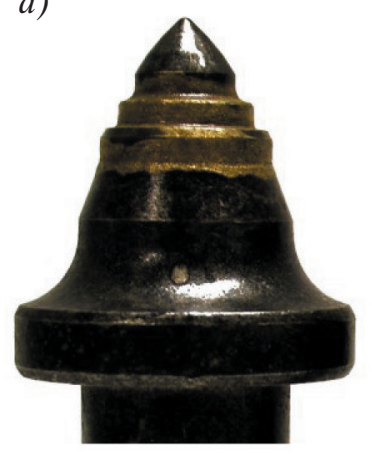

b)

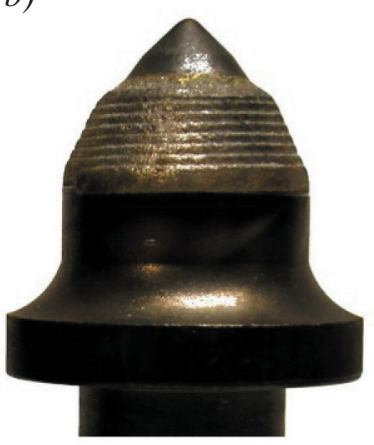

c)

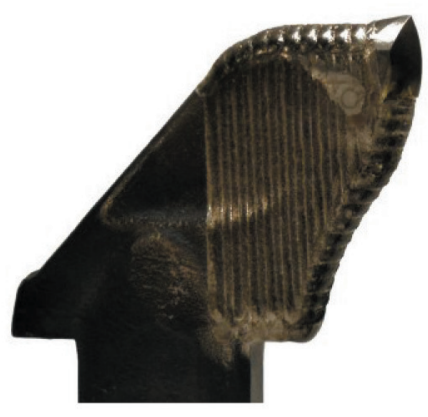

Rys. 3. Sposoby zwiększania trwałości korpusów noży: a) nóż styczno-obrotowy z dodatkowymi pierścieniami $z$ węglika spiekanego na części atakującej; b) nóż styczno-obrotowy z warstwą napawana;

c) nóż promieniowy $z$ warstwa napawaną $[3,8]$ 
a)

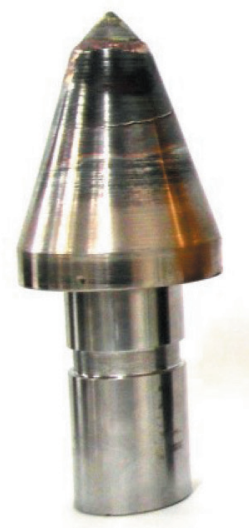

b)

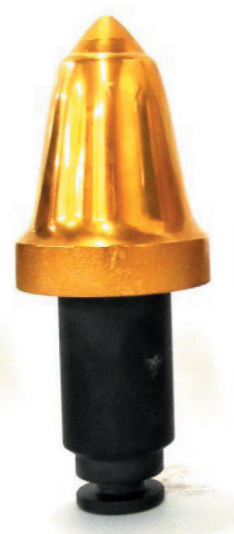

c)

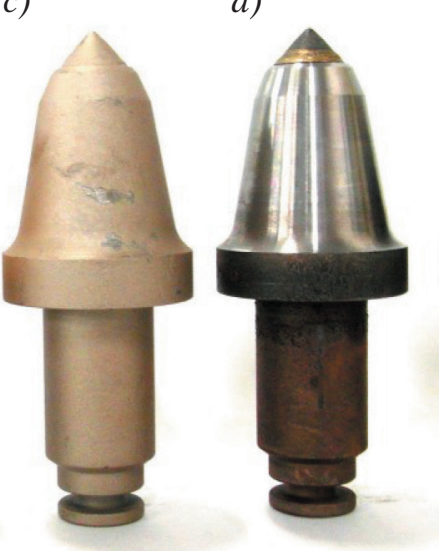

e)

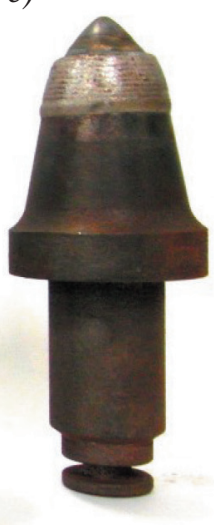

Rys. 4. Wybrane noże przeznaczone do badań: a) „odlewany 22”; b) „złoty 25”; c) „handlowy 22”; d) „srebrny 22”; e) „napawany 25”

- noże napawane laserowo z węglikiem $\phi 22$ (do napawania wykorzystano noże ,handlowy 22”) 4 sztuki - oznaczone jako „napawany 22”,

- noże napawane laserowo z węglikiem ф25 (do napawania wykorzystano noże „handlowy 25”) 4 sztuki - oznaczone jako „napawany 25” (rys. 4e),

- noże z powłoką azotku tytanu z węglikiem ф25 (do napawania wykorzystano noże ,handlowy 25”) 4 sztuki - oznaczone jako „złoty 25” (rys. 4b),

- noże z utwardzonym korpusem z węglikiem ф25 (do napawania wykorzystano noże „handlowy 22”) - 4 sztuki, oznaczone jako „srebrny 22” (rys. 4d),

- noże wykonane przez odlewanie z węglikiem $\phi 22$ (noże odlewane, brak informacji o materiale) 4 sztuki, oznaczone jako „odlewany 22” (rys. 4a),

- noże wykonane przez odlewanie z wkładką ceramiczną zamiast węglika spiekanego (brak informacji o materiale) - 4 sztuki - oznaczone jako „ceramiczny".

\section{PLAN I METODYKA BADAŃ}

W ocenie trwałości noży dostarczonych do badań przyjęto szybkość ich zużycia definiowaną jako łączny ubytek masy noży do objętości urobku uzyskanego podczas próby skrawania sztucznego bloku skalnego [8, 9]. Przyjęta definicja parametru określającego trwałość noży oraz wymagania dotyczące badania szybkości ich zużycia skutkują koniecznością sformułowania następującego planu badań:

- przygotowanie próbki cementowo-piaskowej (cement, piasek, kruszywa, woda) o zadanej wytrzymałości na jednoosiowe ściskanie (wyznaczona empirycznie),
- przygotowanie tarczy badawczej z odpowiednimi uchwytami,

- przygotowanie i oznaczenie noży do badań oraz pomiar ich masy,

- zamocowanie czterech noży styczno-obrotowych na tarczy badawczej,

- urabianie przez frezowanie w warunkach laboratoryjnych przy stałej wartości prędkości posuwu i skrawania,

- demontaż noży,

- pomiar masy noży po procesie urabiania,

- pomiar objętości urobku uzyskanego w czasie pracy badanych noży,

- obliczenie współczynnika C2 określającego szybkość zużycia noży.

Realizacja założonego planu i metodyki wymagała wyznaczenia lub przyjęcia następujących istotnych parametrów związanych z procesem urabiania przedmiotowymi nożami:

- urabianie próbki cementowo-piaskowej składającej się z cementu, piasku i kruszywa bazaltowego o wytrzymałości na jednoosiowe ściskanie $R_{c}=$ $=22,65 \mathrm{MPa}$ i masie właściwej $\gamma_{\mathrm{w}}=2,18 \mathrm{Mg} / \mathrm{m}^{3}$,

- prędkość posuwu $v_{\text {pu }}=0,01 \mathrm{~m} / \mathrm{min}$,

- liczba obrotów tarczy badawczej $n=42 \mathrm{obr} / \mathrm{min}$,

- długość skrawu: 120 mm,

- zabiór skrawu: $152 \mathrm{~mm}$,

- średnica tarczy badawczej po ostrzach: $\phi 1863 \mathrm{~mm}$.

Po wyznaczeniu masy noży przed badaniami i po nich oraz określeniu urobionej przez nie objętości urobku możliwe jest wyznaczenie wskaźnika charakteryzującego szybkość zużycia badanych noży. 
Szybkość zużycia noży (trwałość) określić należy za pomocą wzoru:

$$
\mathrm{C} 2=\frac{\Delta m}{m} \cdot \frac{V_{w}}{V_{u}}[-]
$$

gdzie:

C2 - szybkość zużycia noży na podstawie masy,

$\Delta m$ - ubytek masy noża podczas badań (korpus wraz $\mathrm{z}$ ostrzem) [g],

$m$ - masa noża przed badaniami [g],

$V_{w}$ - objętość wzorcowa próbki $\left[\mathrm{m}^{3}\right]$,

$V_{u}$ - objętość próbki urobiona podczas badań $\left[\mathrm{m}^{3}\right]$.

Objętość wzorcowa $V_{w}$ jest przyjmowana arbitralnie. Objętość próbki urobiona podczas badań $V_{u}$ jest wartością obliczeniową i wyznaczaną na podstawie zmierzonego zabioru, średnicy organu oraz długości wykonanego skrawu [8].

Badania wszystkich typów noży przeprowadza się zgodnie z podaną metodyką i planem badań. Należy zaznaczyć, że im mniejsza wartość parametru C2, tym zużycie noża jest mniejsze. Realizacja badań laboratoryjnych jest w tym przypadku szczególnie polecana, lecz wymaga przeprowadzenia ich na specjalnym stanowisku spełniającym wymagania przyjętej metodyki badań [8].

\section{REALIZACJA BADAŃ}

Przed przystąpieniem do badań wszystkie noże zostały sprawdzone w celu zapisania ewentualnych niedoskonałości, sfotografowane oraz zważone. Następnie każdy zestaw noży został poddany badaniom na poniżej opisanym stanowisku.

\subsection{Stanowisko badawcze}

Badania zostały zrealizowane na stanowisku laboratoryjnym do badania procesu urabiania $\mathrm{w}$ wyniku frezowania lub wiercenia obrotowego pojedynczymi narzędziami skrawającymi lub organami. Służy ono do realizacji kompleksowych badań laboratoryjnych związanych $\mathrm{z}$ szeroko pojętym procesem skrawania skał. Przedmiotowe stanowisko badawcze umożliwia realizację procesu frezowania określonym organem urabiającym sztucznej lub naturalnej próbki skalnej, w warunkach laboratoryjnych. Stanowisko badawcze składa się z trzech głównych podzespołów (rys. 5):

- zespołu napędu organu,

- zespołu mocowania i prowadzenia próbki,

- układu pomiarowego i sterowania.
Zespół napędowy organu urabiającego posadowiony jest na fundamencie i składa się z silnika indukcyjnego prądu zmiennego zasilanego z pośredniego przemiennika częstotliwości sterowanego według zasady DTC o mocy $250 \mathrm{~kW}$ (napięcie zasilania $-3 \times 400 \mathrm{~V}$; liczba obrotów $-1487 \mathrm{obr} / \mathrm{min}$ ). Moment obrotowy z wału silnika przenoszony jest na wał organu urabiającego poprzez przekładnię mechaniczną o przełożeniu $i=28$. Dodatkowo na wale silnika zamontowany został momentomierz. Konfiguracja układu pozwala na pracę napędu w dwóch zakresach, tzw. regulacja na stały moment (do $50 \mathrm{obr} / \mathrm{min}$ ) i regulacja na stałą moc (do $120 \mathrm{obr} / \mathrm{min}$ ). Zespół napędowy zakończony jest wielowypustem, na którym mocowany jest organ urabiający.

Próbka skalna przemieszcza się podłużnie oraz poprzecznie względem organu urabiającego. Ruch zarówno podłużny, jak i poprzeczny próbki skalnej wymuszony jest za pomocą siłowników hydraulicznych, które umożliwiają uzyskanie prędkości posuwu od 0 do $9,9 \mathrm{~m} / \mathrm{min}$, siłę posuwu do $150 \mathrm{kN}$, skok podłużny do 2,5 m, a poprzeczny do 1,3 m. Długość próbki skalnej wynosi 2,5 m, szerokość 1,3 m, wysokość 2,5 m.

$\mathrm{Na}$ stanowisku można badać organy urabiające o maksymalnej średnicy wynoszącej 2,2 m i maksymalnym zabiorze równym $1,0 \mathrm{~m}$. Urobek powstały w czasie urabiania trafia do pojemnika poruszającego się na prowadnicach wraz z urabianą próbką. Rozwiązanie takie umożliwia odbiór urobku w sposób ciągły (w ramach próby pomiarowej).

Układ sterowania, kontroli i rejestracji poszczególnych wielkości związanych z procesem urabiania, umieszczony jest $\mathrm{w}$ kabinie ograniczającej poziom hałasu i zanieczyszczenia. Układ sterowania został wykonany z wykorzystaniem sterowników programowalnych PLC. Do wizualizacji i sterowania procesem wykorzystuje się panel dotykowy oraz pilot zdalnego sterowania. Operator ma możliwość zmiany wszystkich parametrów procesu oraz podgląd aktualnych wartości wielkości rejestrowanych (mierzonych). Układ pomiarowy składa się z czujników umożliwiających wyznaczenie przebiegów, takich jak:

- prędkość posuwu podłużnego,

- prędkość posuwu poprzecznego,

- prędkość obrotowa organu,

- moment oporu skrawania,

- siły w kierunku podłużnym,

- sily w kierunku poprzecznym.

Dodatkowo na stanowisku jest możliwość prowadzenia pomiaru zapylenia podczas badań oraz wykonania analizy uziarnienia otrzymanego urobku. 
a)

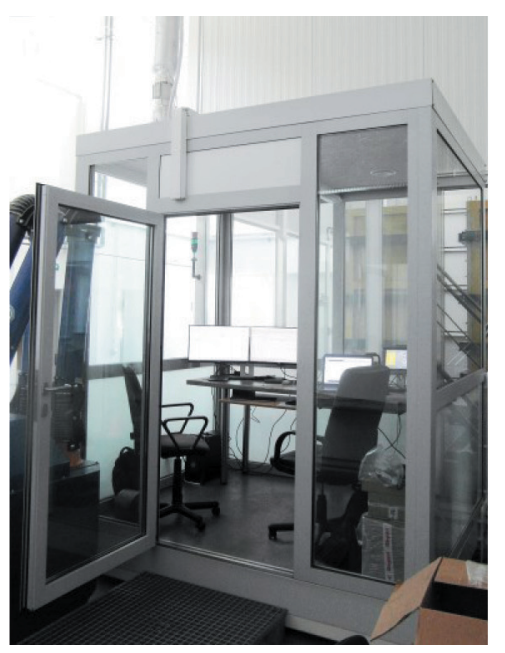

b)

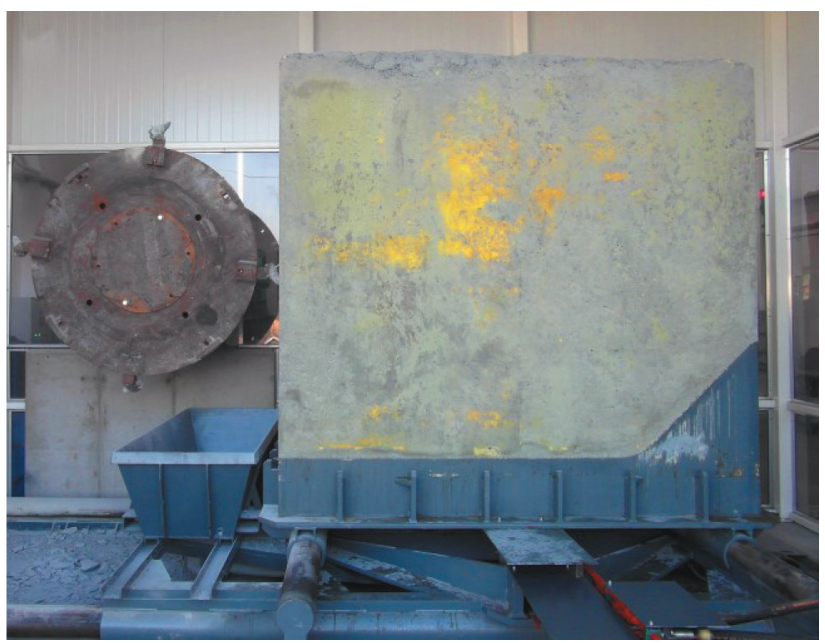

c)

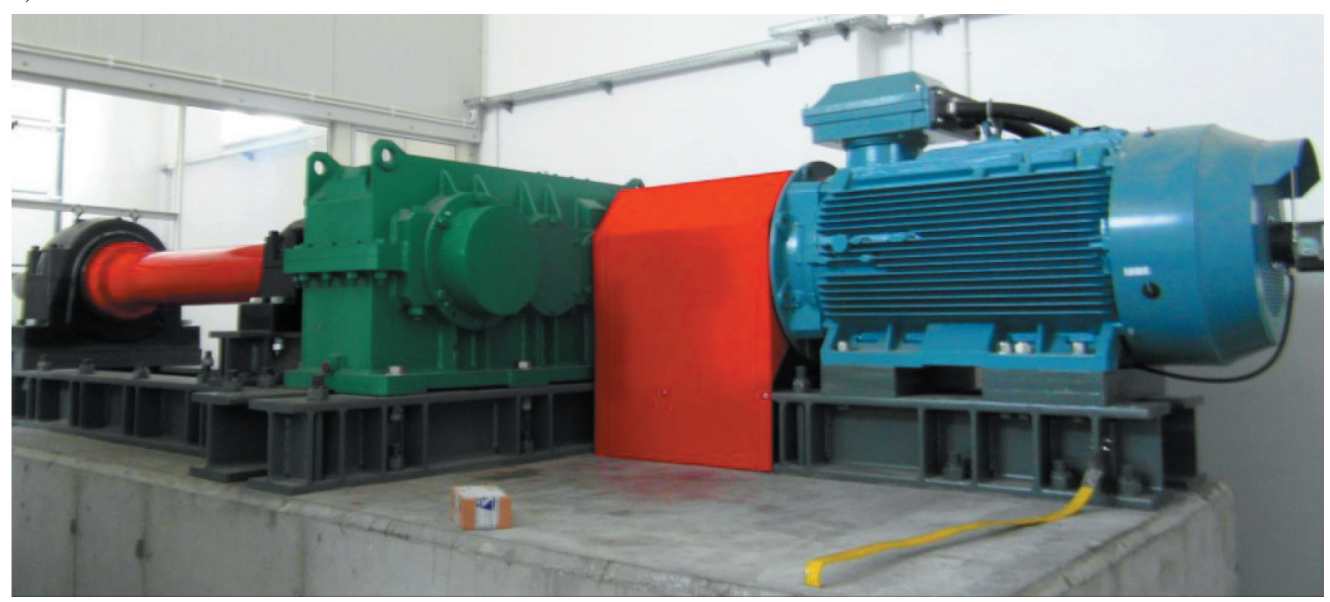

Rys. 5. Stanowisko laboratoryjne do badania procesu urabiania poprzez frezowanie lub wiercenie obrotowe pojedynczymi narzędziami skrawajacymi lub organami: a) kabina operatora; b) betonowa próbka wraz z zespotem jej mocowania i posuwu oraz testowy organ urabiający; c) zespót napędowy organu urabiającego

\subsection{Przebieg badań}

Badania przeprowadzono dla ośmiu kompletów noży zgodnie z opisanym planem i metodyką. Noże na tarczy badawczej tworzyły układ nożowy, którego schemat zamieszczono na rysunku 6. Noże rozmieszczone były na obwodzie co $90^{\circ}$. Każdy komplet noży mocowany był w ponumerowanych od 1 do 4 uchwytach zabudowanych na tarczy. Na rysunku 7 przedstawiono noże zamocowane w uchwytach, przygotowane do badań w poszczególnych próbach.

$\mathrm{Na}$ rysunku 8 przedstawiono wybrane noże po przeprowadzeniu procesu urabiania. Następnie noże zostały przygotowane do pomiaru ich masy, a na podstawie uzyskanych wartości obliczono, zgodnie z założonym planem i metodyką badań, parametry określające szybkość zużycia poszczególnych typów noży.

\subsection{Opracowanie wyników badań}

$\mathrm{Na}$ podstawie zmierzonych wartości oraz podanych wzorów opracowano wyniki badań, które zestawiono w tak zwanych kartach pomiarów. Główną częścią karty jest tabela, której przykład przedstawiono poniżej (tab. 1). Karta pomiarów składa się z dwóch stron. Strona pierwsza zawiera informacje dotyczące wykonawców, realizacji badań (data, parametry próbki), badanych noży (oznaczenie, waga przed i po pomiarach), objętość urobionej próbki, parametr C2 dla każdego noża i wartość średnią.

Na drugiej stronie karty pomiarów zamieszcza się zdjęcia każdego noża wykonane po badaniach (robi się trzy zdjęcia każdego noża co $120^{\circ}$ względem jego osi) (rys. 9). 

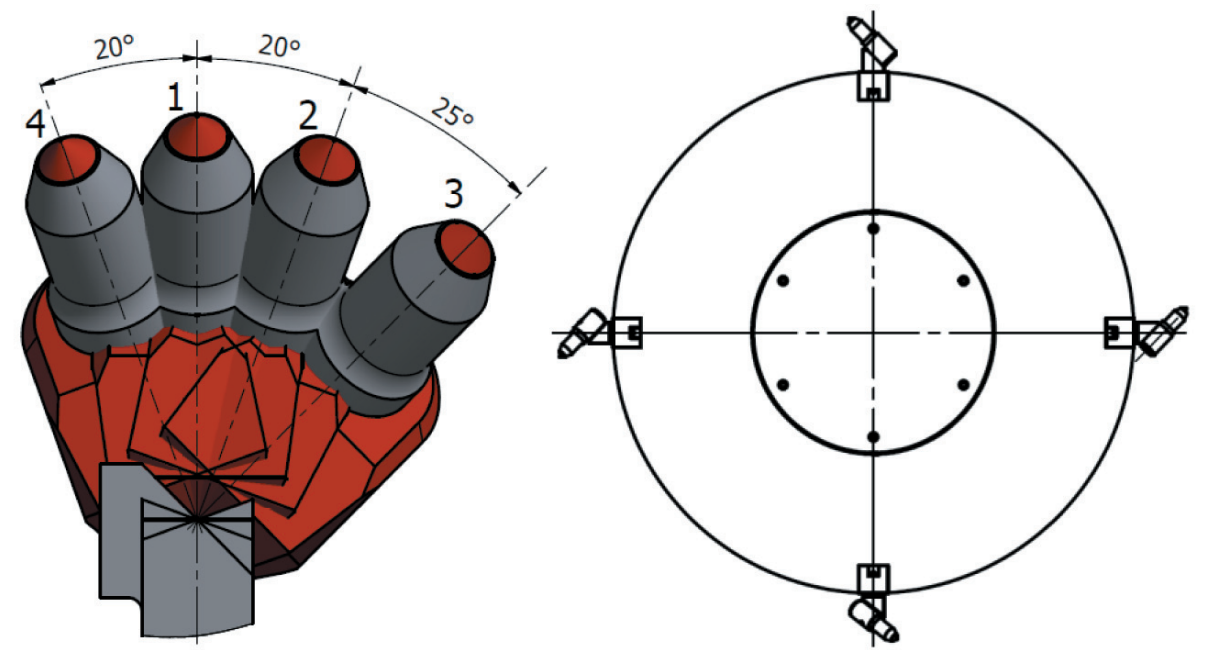

Rys. 6. Schemat zastosowanego układu nożowego z oznaczeniem numerów noży [8]
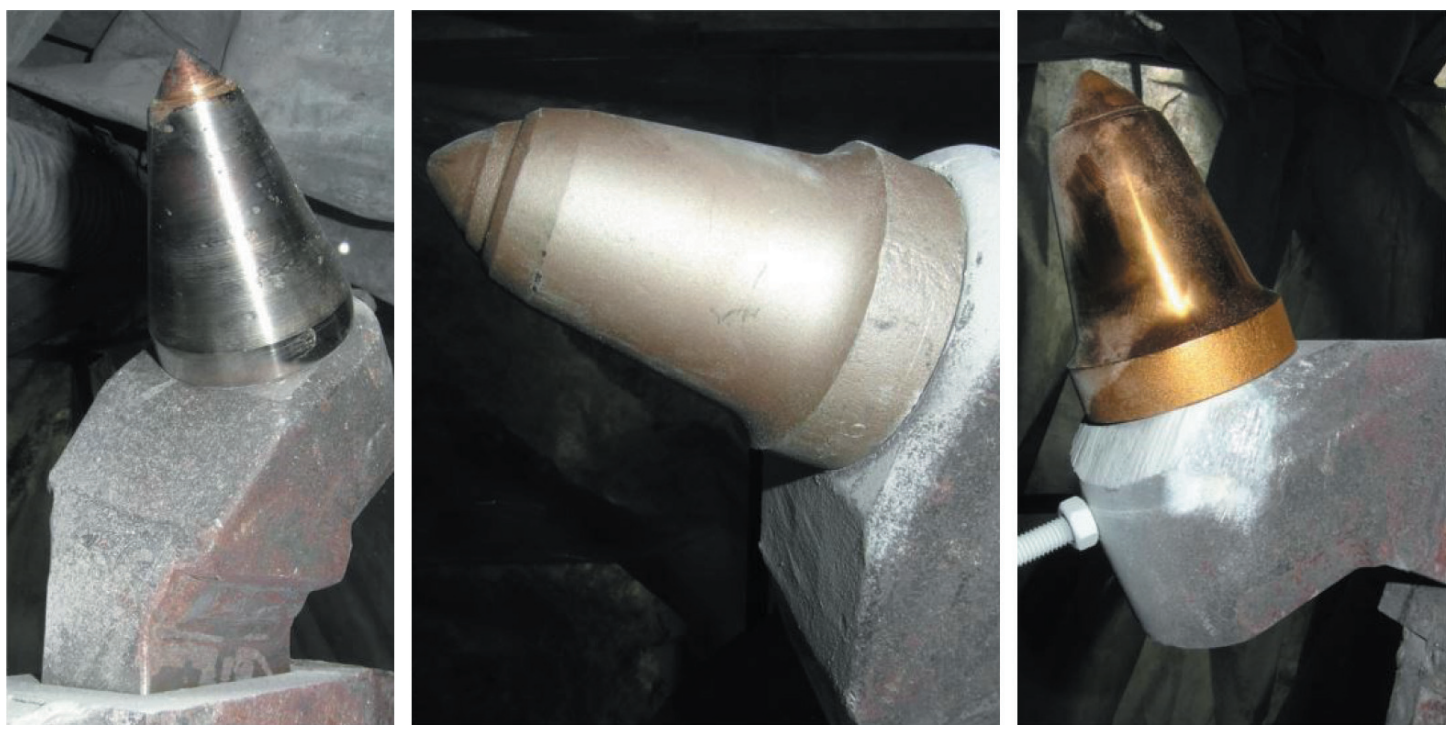

Rys. 7. Przykładowe noże styczno-obrotowe przygotowane do badań

a)

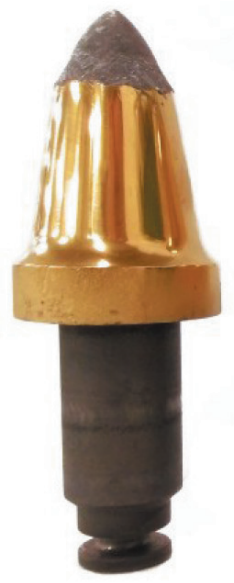

b)

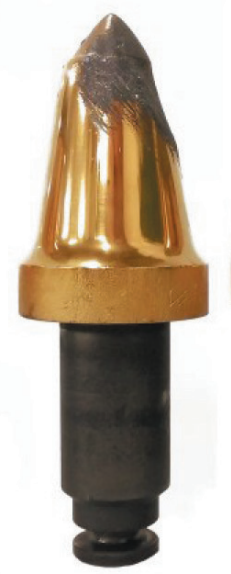

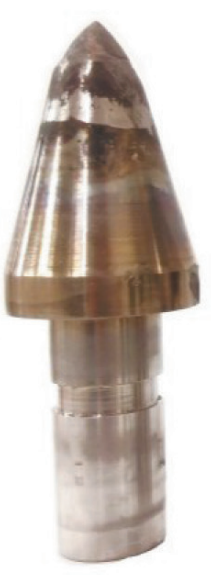

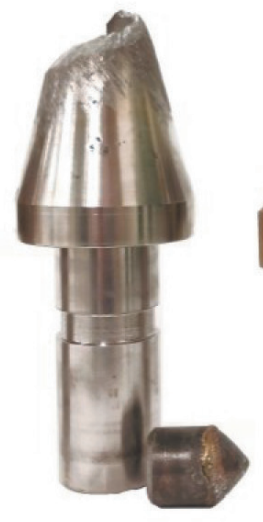

c)

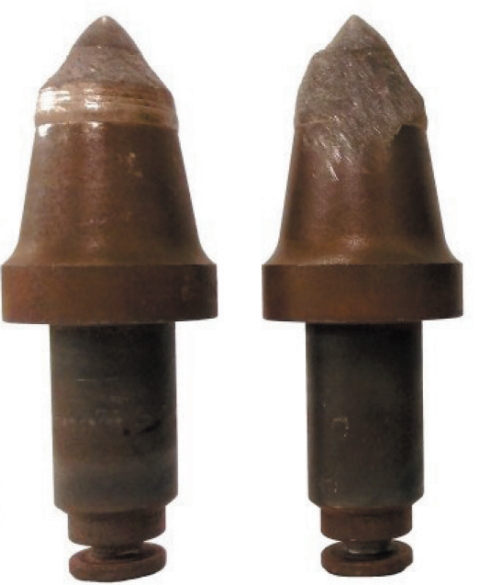

Rys. 8. Wybrane noże po badaniach: a) „złoty 25”; b) „odlewany 22”; c) „napawany 25” 
Tabela 1

Zestawienie wyników badań oraz wyznaczonych parametrów dla noży „handlowy 22”

\begin{tabular}{|c|c|c|c|c|c|c|c|c|c|c|}
\hline \multicolumn{3}{|c|}{$\begin{array}{c}\text { Nóż } \\
\text { „handlowy 22” }\end{array}$} & $\begin{array}{c}\text { Przed } \\
\text { badaniem }\end{array}$ & \multicolumn{7}{|c|}{ Po badaniu, $V_{w}=5 \mathrm{~m}^{3}$} \\
\hline \multirow{2}{*}{ Lp. } & \multirow{2}{*}{$\begin{array}{c}\text { Oznaczenie } \\
\text { noża }\end{array}$} & \multirow{2}{*}{$\begin{array}{l}\text { Oznaczenie } \\
\text { producenta }\end{array}$} & \multirow{2}{*}{$\begin{array}{c}\text { Masa } \\
\text { noża } m \\
{[\mathrm{~g}]}\end{array}$} & \multirow{2}{*}{$\begin{array}{c}\text { Masa } \\
\text { noża } m_{p}[\mathrm{~g}]\end{array}$} & \multirow{2}{*}{$\begin{array}{c}\begin{array}{c}\text { Ubytek masy } \\
\text { noża }\end{array} \\
\Delta m=m-m_{p}[\mathrm{~g}]\end{array}$} & \multicolumn{3}{|c|}{ Zdjęcia } & \multirow{2}{*}{$V_{u}\left[\mathrm{~m}^{3}\right]$} & \multirow{2}{*}{ C2 [-] } \\
\hline & & & & & & $0^{\circ}$ & $120^{\circ}$ & $240^{\circ}$ & & \\
\hline 1 & 1 & - & 1830,14 & 1809,69 & 20,45 & 1-I & 1-II & 1-III & 0,0539 & 1,036 \\
\hline 2 & 2 & - & 1828,49 & 1795,85 & 32,64 & $2-\mathrm{I}$ & 2-II & 2-III & 0,0539 & 1,655 \\
\hline 3 & 3 & - & 1828,80 & 1792,85 & 35,95 & $3-\mathrm{I}$ & 3 -II & 3-III & 0,0539 & 1,822 \\
\hline 4 & 4 & - & 1828,40 & 1793,48 & 34,92 & $4-\mathrm{I}$ & 4-II & 4-III & 0,0539 & 1,771 \\
\hline \multicolumn{9}{|c|}{ Średnia parametru względnego ubytku masy noża C2: } & \multicolumn{2}{|c|}{ C2: 1,571} \\
\hline
\end{tabular}

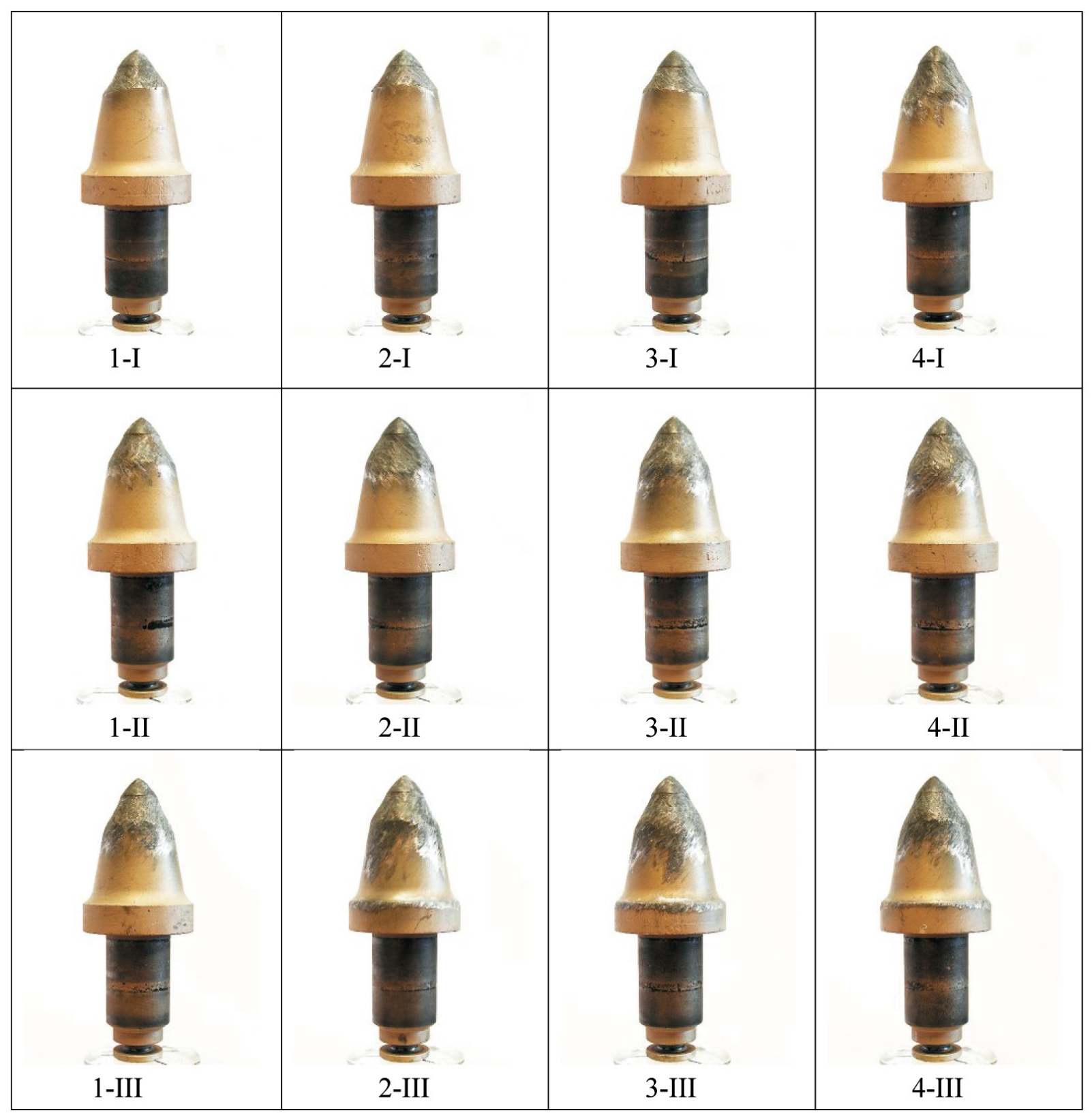

Rys. 9. Zdjęcia noży „handlowy 22” po badaniach wykonane co $120^{\circ}$ względem osi noża 


\section{OCENA TRWAKOŚCI BADANYCH NOŻY}

W ramach realizacji badań szybkości zużycia (trwałości) noży styczno-obrotowych przeprowadzono osiem prób skrawania nożami. W wyniku przeprowadzonych badań oraz stosownych obliczeń opracowano wyniki. Na podstawie ich analizy można stwierdzić, że noże oznaczone jako „złoty 25 ” oraz "handlowy 22" i „handlowy 25" charakteryzowały się najmniejszą szybkością zużycia.

Poniżej przedstawiono uwagi dotyczące poszczególnych noży:

- „handlowy 22” i „handlowy 25” (noże fabryczne) uzyskały bardzo dobry rezultat,

- „napawany 22” i „napawany 25” - pomimo zastosowania napawania laserowego uzyskały rezultat nieznacznie gorszy od noża handlowego, który wykorzystano do ich wykonania,

- „złoty 25” - uzyskały najlepszy rezultat, jednak zastosowanie powłoki z azotku tytanu zwiększyło jedynie nieznacznie ich wytrzymałość na zużycie ścierne,

- „srebrny 22” - pomimo zastosowania specjalnej obróbki korpusu (nie ujawniono, na czym polegał przeprowadzony proces) uzyskały rezultat nieznacznie gorszy od noża handlowego, który wykorzystano do ich wykonania,

- „odlewany 22” - nóż odlewany, toczony po odlaniu do wymaganych wymiarów, korpusy noży pękły po umieszczeniu węglika spiekanego, noże na pozycji 2 i 3 zostały wyłamane podczas badań,

- „ceramiczny” - nóż odlewany, toczony po odlaniu do wymaganych wymiarów, zużyły się wyjątkowo szybko pomimo czterokrotnie mniejszej objętości urobionej próbki, nóż na pozycji 2 wykruszył się, a nóż na pozycji 3 złamał się w części chwytowej.

\section{ZAKOŃCZENIE}

Jak przedstawiono w niniejszym artykule, sposobów zwiększania trwałości i zmniejszania szybkości zużycia noży styczno-obrotowych jest wiele. Obecnie najbardziej popularne i przynoszące najlepsze efekty jest napawanie części roboczej warstwą odporną na ścieranie. Jednakże, jak wynika z przeprowadzonych badań, nie zawsze jest to najlepsze rozwiązanie. Dodatkowo można stwierdzić, że nawet najlepsza powłoka ochronna nie spełni swojej funkcji, jeśli nóż lub jego ostrze będzie wykonany ze słabej jakości materiału.

Na pewno celowe jest dalsze prowadzenie prób dla zwiększenia trwałości noży, gdyż ma ona bardzo duży wpływ na obniżenie kosztów eksploatacji, a tym samym cen wydobywanych surowców.

\section{Literatura}

[1] Krauze K.: Urabianie skat kombajnami ścianowymi, Wydawnictwo Naukowe Sląsk, Katowice 2002.

[2] Krauze K., Klempka R., Mucha K.: Computer - aided design of cutting heads, „Mining - Informatics, Automation and Electrical Engineering" 2015, 4: 22-32.

[3] Krauze K., Mucha K.: Zwiększenie odporności na zużycie ścierne noży kombajnowych, „Przegląd Górniczy” 2016, 1: 63-67.

[4] Jonak J.: Urabianie skat głowicami wielonarzędziowymi, Wydawnictwo Naukowe Slask, Katowice 2002.

[5] Kotwica K.: Effect of selected working conditions of cutting picks on their wear during the mining of hard rocks, „Quarterly Mechanics and Control" 2010, 29, 3: 110-119.

[6] Bołoz Ł.: Ocena obciążenia jednoorganowego kombajnu ścianowego na podstawie badań analitycznych [praca doktorska], Kraków 2012.

[7] Kotwica K., Gospodarczyk P.: Hard Rock Mining with use of New Cutting Tools, „Journal of Mining Sciences” 2003, 39, 4: 387-393.

[8] Krauze K., Bołoz Ł., Wydro T.: Parametric factors for the tangential - rotary picks quality assessment, „Archives of Mining Sciences" 2015, 60, 1: 265-281.

[9] Krauze K., Bołoz Ł., Wydro T.: Ocena jakości noży stycznoobrotowych na podstawie badań laboratoryjnych, „Mechanizacja, Automatyzacja i Robotyzacja w Górnictwie: monografia 2012”, Lędziny 2012.

[10] Krauze K., Skowronek T., Mucha K.: Influence of the hard faced layer welded on tangential - rotary pick operational part on to its wear rate, „Archives of Mining Sciences” 2016, 61, 4: 779-792.

[11] Sandvik Coromant: http://www.sandvik.coromant.com [dostęp: 24.04.2017].

[12] Kotwica K.: The influence of water assistance on the character and degree of wear of cutting tools applied in roadheaders, „Archives of Mining Sciences” 2011, 56, 3: 353-374.

prof. dr hab. inz. KRZYSZTOF KRAUZE

dr inż. $Ł U K A S Z$ BOEOZ

dr inż. TOMASZ WYDRO

mgr inż. KAMIL MUCHA

Wydziat Inżynierii Mechanicznej i Robotyki AGH Akademia Górniczo-Hutnicza im. Stanisława Staszica w Krakowie

al. A. Mickiewicza 30, 30-059 Kraków

\{krauze, boloz, wydro, kmucha\}@agh.edu.pl 